\title{
The Penetration of American Value: American Companies’ Ads in China
}

\begin{abstract}
Su Jiangli
Shanxi University, Taiyuan, China

In an information age, soft power and smart power coined by Joseph Nye has captured the imagination of academics and politicians around the world. He distinguishes between soft power as a guiding principle and public diplomacy as an executive practice when he combines soft power with Mark Leonard's three principal dimensions of public diplomacy: daily communication, strategic communication and building lasting relationship. Nye views American culture values as an element of soft power and he thinks American companies play an important role in boosting the country's soft power. Advertisements have long been the main weapon for American companies to attract other countries' consumers and advertise American culture values and way of life. By analyzing American movie trailers, car ads and commercials of fast food chains, this essay wants to present how American companies exert their influence in the field of public diplomacy and transform abstract soft power of culture values and way of life into tangible and visible forces.
\end{abstract}

Keywords: soft power, public diplomacy, advertisements, culture values, way of life

\section{Introduction}

It is known to all that "soft power" is a term used to describe a nation's use of co-operative programs and financial assistance to persuade other nations to ascribe to its policies or attract other nations to follow its policy trajectories unconsciously. Dr. Joseph Nye, Jr., a noted foreign policy scholar and practitioner, coined the phrase "soft power" in 1990. He has written and lectured extensively on the idea and usage of soft power ever since.

Nye (2004) describes soft power as "the ability to get what you want through attraction and persuasion rather than through coercion” (p. 5). He views strong relations with allies, economic assistance programs, and vital cultural exchanges as examples of soft power. For Nye the soft power of a country rests primarily on three resources: its culture, its political values and its foreign policies. He sees American cultural exports—such as movies, soft drinks, and fast-food chains — as an element of soft power. He believed that American corporations shoulder the responsibility of projecting American cultural values abroad (Nye, 2008): “American companies can also play an important role. Their representatives and brands directly touch lives of far more people than government representatives do" (p. 101).

In terms of public diplomacy, Joseph Nye distinguishes soft power as a guiding principle and public diplomacy as an executive practice when he combines the three above principal concerns he attributes to soft power with Mark Leonard's three principal dimensions-or practices-of public diplomacy: daily 
communications, strategic communications, and building lasting relationships.

Advertising, in the widest sense, has always been appreciated in the United States, which spends more for this purpose than any other country (Laqueur, 1994, p. 19). While American corporations spend huge amounts selling movies, cars and soft drinks, they are also promoting American values, institutions and way of life.

This research will explore how some American movie trailers and TV play ads, cars, soft drinks, and fast-food chain commercials represent a great force to amplify the country's voice, boost its image, build positive perceptions of the countries' foreign policies, and have an impact on Chinese teenagers and middle class.

\section{American Companies' Ads and Public Diplomacy}

Leonard (2002) has proposed three dimensions to effectively conduct public diplomacy, and Nye (2008) believes these are viable means to materialize a country's soft power. One of the main objectives of a country's foreign policy is to get other nations to adopt its policy goals as their own ones and to frame or shape others' policy agendas or even their preference. So, public diplomacy has become an important tool which can help to achieve that effect without pumping funds, and deploying military forces like marines or seals, or aircraft carriers. However, for the post modern generation in the information age propaganda is poisonous. They would filter it automatically. So, it is meaningful for public diplomacy to move into the vacuum. Apart from public relations campaign and conveying information and shaping positive image, public diplomacy entails "building long term relations that create an enabling environment for government policies” (Nye, 2008, p. 103).

This essay contends that American companies' ads can actually fulfill the three dimensions, thus convert invisible soft power into highly visible presence and forces. Ads might not explain the US government's domestic and foreign policy decisions like VOA, PBS or NPR, but they do communicate ideas like who are Americans and how do they live their lives. In order to sell their products they also take steps to infiltrate into the market strategically. Chinese elements are added to their Ads campaigns to appeal to the customers but underneath the localized clothes they have an American heart. So they could instill their values and practice into Chinese customers, especially young people. Consumer loyalty also helps to establish lasting relationship with the culture. It is hard to imagine when other people like a country's food, admire its heroes, enjoy its music, and watch the same TV plays with its people would not be affected by that country's culture values. That's why Nye (2008) emphasis that "public diplomacy is an important tool in the arsenal of smart power". "American companies can also play an important role. Actually, companies can take the lead in sponsoring specific public diplomacy project” (pp. 105-108).

Nye (2008) also notes that "when people are overwhelmed with the volume of information confronting them, it is hard to know what to focus on. Attention rather than information becomes the scare resource, and those who can distinguish valuable information from background clutter gain power" (pp. 100-101). Cue-givers become more in demand, and this is source of power for those who can tell us where to focus our attention. Ads are effective cue givers because it's short, concise, and the message is sent with special visual and sound effects to impress the audience or readers.

American movie trailers, which act as ads for American movies promise to advance and reinforce the image of Americans as a people with mission and they could sacrifice their own wellbeing for common good. Meanwhile they also reach out to the audience like friends which helps to establish long-term relationship, and even loyalty among different generations of Chinese audiences. For example, Superman, Batman, Spiderman, 
Transformers, and Ironman have won over Chinese fans because the different episodes, which tell a story for more than 20 years continuously might remind them of the different stages of their lives: happy childhood, ambitious youth and practical adults who still longing for the past. Ads for Ford automobiles and GM Chevrolets aim at the rising Chinese middle class who embrace the image of an unstoppable man wielding the power of modern technology to serve his needs to move upwards. Or fashionable and educated young women take advantage of the friendly vehicle to balance her needs to pursue a career and caring for kids. The relationship between material things and its owners are upgraded to the extent that their cars are actually their companions on their way to make their dreams come true. CoCa-Cola is the spokesman of happiness when friends come together, family reunited, and tired travelers are on their journey home. Coca-Cola helps to cheer a frustrated friend up when giving him (her) a drink and tell them "you are the prince (princess) of happiness; or you are my buddy". ' Coke is not a drink anymore; it's a creator of happiness during our holidays and special moments. Fast-food chains like KFC, McDonald, Papa John's, and Pizza Huts are not only places to eat something but a place to share our secrets with friends and families. They become parts of our life.

\section{American Movie Trailers and Its Influence on Chinese Youth}

Nye (2012) says that "conventional wisdom has always held that the state with the largest military prevails, but in an information age it may be the state with the best story wins" (p. 10). That can be understood as a nation's power increasingly rests on its "capacity to create and manipulate knowledge and information" (Wilson, 2008, p. 112).

Cultural products especially American movies and TV plays have effectively manipulated thousands of young Chinese audience's imagination about the United States. They are fascinated with the stories and repeatedly impressed by the freedom, openness of the society and communication dynamics presented in the movies.

Since movie trailer is the highly condensed form of art with a normal length of two and a half minutes, it needs to showcase the essence of the movie and highlight the core themes it wants to convey. It sends a more direct and powerful message than the whole movie itself might do. And it has a large audience in China, and almost all the hot Chinese Internet video platforms such as youku.com, tudou.com, sohu.com, ku6.com, iqiyi.com, letv.com and pptv.com provide trailers of American movies. Some passionate fans mix and create their own ones and place them on their blog spheres; some share their ideas and comments in the circle of friends on Wechat. So it is a useful perspective to explore American movies' influence on Chinese youth.

\section{American Heroes Are "Saving the World"}

Common Chinese young viewers have no idea of American exceptionalism, Manifest Destiny, or idea of mission, so they do not examine the messages of American movie trailers critically. They are fascinated with the legendary heroes and their resilience. The emotional, suspenseful, action packed or humorous moments accompanied by a series of visual montages can always effectively capture their imagination. The voiceover, powerful music and high-tech packed lifelike scenes do have an influence on them. The trailers always reinforce and highlight the themes of the coming movies. Of course, these are value loaded.

No wonder Hillary Clinton (2010) once said, "More than our military might, and more than the size of our economy, our precious asset as a nation is the persuasive power of our values" (p. 4).

\footnotetext{
${ }^{1}$ Happiness Creator. Coca Cola ads. Retrieved October 26, 2014, from http://www.coca-cola.com.cn/
} 
From Superman, Batman, Spiderman to Ironman, American heroes all assume the responsibility of protecting the world and make it a better place to live in. Even the villain in Despicable Me 2 tells his two step daughters, "Dad is going to save the world" (2013).

In June 2013, the Warner Brothers released the reproduced Superman movie Man of Steel in 3D format. The trailer is epic. It combines the modernized interpretation of the Superman origin and mythos with a barrage of montage scenes. In the trailer, the Superman under the assumed identity of ordinary Kansas small town boy Clark was born with a mission to protect the earth for a better future. The voiceover says forcefully, "Whoever that man is, he is going to change the world" (2013).

As American culture icon, Batman is the crime-buster and symbol of justice. First appeared in comic books, it has been adapted into a variety of media: radio shows, TV plays, games and movies. In the 1992 Warner Brothers movie Batman Returns, the superhero said, "I have been hiding for too long, and it's time for me to ascend... I'm the only one who can save the city” (1992).

Distributed by Columbia Pictures in June 2004, the Spider-Man 2 describes the growth of a hero who is struggling to manage both his personal life and duties as spider-man. The trailer begins with the narration: "I believe there is a hero who gives us strength, makes us noble. Even though sometimes we have to give up the things we want most". And it ends with a screen text "A hero is revealed" (2004), after presenting the thrilling scenes of how the hero finally determines to face his destiny as a hero.

The 2013 Paramount movie Iron Man 3 is another superhero movie and a sequel to 2008's Iron Man and 2010's Iron Man 2. In the trailer, the billionaire, industrialist, and ingenious engineer Tony Stark who has successfully upgraded his powerful armor and used it to protect the world as iron man says, “...occasionally I save the world" (2013).

\section{Americanized Chinese Elements}

While major Hollywood studios have seen decreased earnings in the domestic market, offshore box office earnings totaled a record \$13.6 billion in 2011, with China as one of the major forces driving up ticket sales. According to a Beijing Review article, in 2010, China’s film market generated 13.1 billion yuan ( $\$ 2$ billion), of which 4.9 billion Yuan, or 37\%, was generated by ticket sales for US blockbusters (2012, Para. 6). In 2013, US science fiction blockbuster Pacific Rim has stayed at the top of China's box office charts for three consecutive weeks, while it performed poorly in its home market. China Daily reported that, according to box office estimation made by China Film News, the movie about monsters set in the 2020s, had taken 640 million Yuan (\$104.5 million) while it only took \$52.3 million in its first week at the US box office and dropped by $57.2 \%$ in the second week (2013, Para. 4). Other US movies like Fast and Furious 6 and White House Down, also had a better box office prospect in China than the domestic market. In June 2014, Transformers: Age of Extinction has taken more than \$306 million in China alone, far more than the film’s North America gross of \$227 million (Shone, 2014, Para. 5). Since the first American movie, The Fugitive, was introduced into Chinese market in 1994, Chinese viewers have increasingly contributed to Hollywood's earnings, which has propelled the American movie makers look east and added Chinese elements to their movies.

From Disney’s 1998 animated feature Mulan, Dream Works' 2011 hit Kung Fu Panda 2, the disaster, adventure movie 2012, James Cameron's Avatar, to Paramount's 2013 movie Iron Man 3, Hollywood blockbusters have been enjoying success through their use of Chinese elements. But these Chinese elements are Americanized. American movie makers interpret Chinese stories, symbols and heroes from the perspective of 
American culture and value system.

Trailers are ads for the coming movies, so movie producers make efforts to ensure the Chinese elements are included. However, the Chinese ingredients are made to join the American chorus to help spread the American messages.

In the Disney animation, Mulan becomes an American hero, and in the trailer she even says "I have a mission" (1998). And the pint-sized, lizard-like dragon her ancestors sent to assist her has definitely distorted the solemn image of dragon in Chinese culture. Even if the voiceover in the trailer says "she would risk everything to honor her family" (1998), it has totally betrayed the significance of Mulan in Chinese culture where Mulan challenges the women's image as men's shadow or affiliated object.

In the Dreams Work movie, Kung Fu Panda does not symbolize friendship, kindness, or personal perfection but assumes the responsibility to save Kung Fu. So he is another typical American superhero born with a mission to save the world. In the trailer, the Master emphasizes repeatedly "You must save Kung Fu... Take the five and save us all”. And it ends with the Master's teaching, the classical American propaganda, "When you follow the noble path, anything is possible" (2011).

Walt Disney studio has created an Iron Man 3 trailer specifically for Chinese market in synch with its Chinese version of the movie. In the trailer, a fleeting scene of Chinese actress Fan Binbin causes quite a stir among Chinese fans, but she has nothing to do with the theme of the movie; she is not even the spice for the movie. Another Chinese star Wang Xueqi also has a short appearance. According to the news report from International Channel Shanghai, the Chinese trailer helped its American producer garner a record 130 million yuan - more than any other Hollywood blockbuster like Titanic or Avatar — on its opening day in China (2013, Para. 5). But some rational fans are disappointed. One of the comments from a netizen named little brother, posted after the trailer from tudou.cm said, "Wang Xueqi's role is totally meaningless, and Fan Binbin's appearance is just like drawing a snake and adding feet to it” (2013).

\section{Advertising American Dream to Chinese Middle Class}

The Brooking Institution's Homi Kharas and Geoffrey Gertz (2010) estimate that the global middle class population will hit 4.9 trillion by 2030, and they will spend \$56 trillion a year. Virtually all that growth will come from emerging economies, especially China, which is a big promising market. In China alone, "there could be more than 670 million middle class by 2021” (pp. 2-3). It is a classic strategy: reach the growing middle classes by selling them not just a product, but a lifestyle, an aspiration.

Relying on the rhetoric of American dream to sell cars is as old as American cars. Even during the Great Depression eras, American automakers advertised their cars by using beautiful pictures featuring middle class men and women with their kids leaving their suburban houses to have picnics by the rivers. Now they become a strategy to win over the Chinese middle class. One of Ford Kuga ads features a middle class family going back home after a picnic by the river and mountain. The kid falls asleep and the mum uses voice control to adjust the temperature in the car. In the meanwhile the voiceover says: "A smart car can sense your needs. That's personally tailored technology". ${ }^{2}$ Ford and GM are not only selling cars in China but American way of life and culture values, and American style dream.

${ }^{2}$ Ford Kuga ad. (2013). Retrieved from October 20, 2014. http://v.youku.com/v_show/id_XNTM4ODYxOTg4.html?f=19352288 
In Ford ads, there are always sharply dressed middle class women and ambitious middle class men. Ford cars can help these professional women pursue a successful career and take care of the kids; whereas men are energetic and determined. They are driving Ford to conquer the world. In one of the Ford Mustang ads, an ambitious man is driving the car through skyscrapers and highways to "go further" to tame the "tropical jungle of the metropolitan city". ${ }^{3}$ In a New Focus ad, the car is depicted as man's companion to achieve his life's goal by following his heart rather than flowing with the crowds. A man is driving the car through green fields and busy cities with a voiceover reveals that he is driving the car to experience real road to success which promises to shorten the distance between the self awareness and the harsh reality. "While I am opening my eyes in the morning I ask myself that the first beam of light is a new beginning or the shadow of yesterday. While I close the door of my car, I ask myself the direction I am following today is my heart's desire or the tide of the times. While I steer my car, I ask myself if it's me who is the driver of my life or I am driven by life. From the very beginning, we know what we want. Let’s experience real road to our goals with Ford”4.

In the ads of General Motor, there are always confident men who assume the responsibility of providing a better life for the family and work hard to fulfill dreams. For instance, a Buick ad features a man with courage, passion and responsibility to pursue his dream. And both the camera and the voiceover reveal that the man is motivated by the love for his family. In one of the Chevrolet Epica ads, a middle class man recalls his father working hard to make his life happy and comfortable while he is driving his Epica to take his parents, wife and kid for an excursion on a fine spring day. And the voiceover says, "Men’s love for his family will linger long in their hearts”. ${ }^{5}$ A very popular Buick ad describes three middle-class men works together for a successful career. The motivation for them to move ahead is their love for their families. The ad begins with a little boy singing "I believe I Can Fly" and the music accompanies the three men's fighting to go ahead.

\section{Experiencing American Way of Life in American Fast Food Chains}

Starbucks CEO Howard Schultz often talks about selling an experience; coffee is an afterthought. What sociologist George Ritzer (2008) describes about Starbucks in his book The McDonaldization of Society 5 reflects the truth of increasing cultural importance of American fast food chains in China.

Starbucks has become important not only economically but, of perhaps even greater significance, culturally. Arguably, it is fast becoming the world's coffee house and destination not only for commuters but for students in search of a place to study, for business people in need of a place to work and even hold meeting, and for parents of young children to meet and socialize. (p. xiiii)

Ads of American fast food Chains from Pizza Hut, Papa John's, KFC, and Burger King to McDonalds emphasize that ubiquity and cultural importance, even if in their ads, they use ordinary Chinese people and have also localized their tastes. These are their tactics to achieve the effect of "we are one of you". Actually, they still have an American heart and eating in these fast food chains tantamount to having a taste of American way of life. As Ritzer criticized in an interview (June 1997), American corporations try to create a duplicitous image, a false image "we are the world" (2008, Para. 8).

In his book The Lexus and the Olive Tree, Thomas Friedman (2000) uses glocalization to describe a paradoxical trend of globalization. He defines glocalization as "the ability of a culture, when it encounters other

\footnotetext{
${ }^{3}$ Ford Mustang ad. (2013). Retrieved October 20, 2014, from http://www.tudou.com/programs/view/iOICsmDvbZc/

4 Ford New Focus ad. (2013). Retrieved October 21, 2014, from http://www.tudou.com/programs/view/iOICsmDvVZc/

${ }^{5}$ Chevrolet Epica ad. (2013). Retrieved October 19, 2014, from http://www.tudou.com/programs/view/iOICsmDvZcc/
} 
strong cultures, to absorb influences that naturally fit into and can enrich that culture, to resist those things that are truly alien and to compartmentalize those things that, while different, can nevertheless be enjoyed and celebrated as different” (p. 56). For example, Friedman thinks good glocalization is when a little Japanese girl goes to a McDonalds in Tokyo to "enjoy the American way of life and food". Bad glocalization is when she gets off a plane in Los Angeles and is surprised that "they have McDonalds in America, too!” (p. 56). The little girl should be aware that McDonalds is not a part of the Japanese culture. Otherwise we are headed for a very bland world: all Lexus and no olive tree. But the truth is reading American fast food chains' ads in China closely, we will find that those Multi-Nationals are trying to cloth those truly alien things with localized garments and sell the garments and the essence of the alien culture at the same time.

They are not only selling hamburgers or pizzas but a cultural icon. For example, the brand story of Papa John's tells the story of American dream and way of life: “As a high school student working at a local pizza hub, Papa John's founder John Schnatter had a dream to open a pizza restaurant one day that would make superior-quality traditional pizza and delivered to the customer's door. In 1984, John Schnatter sold his prized 1972 Z28 Camaro purchased \$1,600 worth of used restaurant equipment and began selling his pizzas to the tavern's customers. Today, there are approximately 4,000 Papa John's restaurants all over the world. More importantly, Papa John's remains committed to its heritage of making a superior-quality, traditional pizza."6

Whereas, the ads of KFC which has 4,500 outlets in China describe the fast food restaurant as a place to have home-made breakfast, luxury lunch, and comfortable supper. It's also a place for college students to meet friends in summer vacation.

Meanwhile, McDonald ads describe the restaurant just like any other diners in the US neighborhood—It's a special place for people who live there because it's a place that bears witness to their happiness and sorrow. In one of the McDonald TV commercials, the fast food chain is depicted as a place for the grandson who gets top grades in the class to treat his grandmother with his favorite McDonald hamburger. More meaningfully, at the very beginning of the video, the grandson Doudou runs to the restaurant to tell the "sister" working there that his grandma will come to spend the spring festival with him tomorrow.

In another series of commercials named "It's McDonald who let us be together happily", McDonalds are the place for young peoples to meet friends and make friends, for lovers to stick to each other, and for kids where there is McDonald it makes a good place to live. One video in the series features a little boy says sadly to the toy Grandpa McDonald, "I have moved house so I cannot be with you anymore". The father sees this and takes him to the window from where he finds the golden arch of McDonald. The little boy exclaims excitedly, “Mum, Grandpa McDonald has also moved here”. Another one presents how a young man eating in McDonald meet the other two and they decide to play tennis together and become friends. A third one in the series depicts two young lovers talking about their future plans while eating big Macs and McNuggets. In the video, the young man is talking about his coming interview and a better future prospect and his talk is interrupted when the camera shows another man driving an expensive car and stops at a fancy house. The beautiful young woman senses something and tells her boy friend "he has expansive car and house, but you always have me". And the voiceover says, "It is McDonald who let us be together happily". 7

\footnotetext{
${ }^{6}$ Brand Story of Papa John's. Retrieved October 16, 2014, from http://www. papajohnschina.com

7 It is McDonald Who Let Us be Together Happily. McDonald Commercial in China. (2014). Retried from October 26, 2014, from http://www.letv.com/ptv/vplay/0320846.html
} 


\section{Conclusions}

From analyzing American movie trailers, car ads and fast food chain commercials, this essay argues that American Corporations in China assume the responsibility of spreading American cultural values. They are not only advertising their products but also advertising American culture, American dream and American way of life to Chinese consumers. So they represent an important part of American soft power. They can actually fulfill the three dimensions of public diplomacy: daily communication, strategic communication and building lasting relationship. Therefore, they may convert the abstract soft power of culture values into something more visible and tangible. Plus, because they directly touch the lives of ordinary people, the influence is pervasive which might pose a threat to the preservation and inheritance of traditional Chinese culture values. Given that soft power also come from the voluntary efforts of civil society, Chinese companies have the responsibility to compete with their American counterparts rather than merely relying on government sponsored programs.

\section{References}

Batman. (June 1998). Two minutes movie trailer. Retrieved October 23, 2014, from http://v.youku.com/v_show/id_XNDgwNzE4NzQw.html?tpa=dW5pb25faWQ9MTAzMzUyXzEwMDAwMl8wMV8wMQ

Clinton, H. (2010). America's engagement in Asia-Pacific. Remarks delivered at Kahala Hotel, Honolulu, HI, Oct. $28,2010$. $\begin{array}{llll}\text { Retrieved } \quad \text { October } & 26, & 2014 \text {, }\end{array}$ http://www.cfr.org/asia-and-pacific/clintons-speech-americas-engagement-asia-pacific-october-2010/p23280

Despicable Me 2. (2013). Two minutes movie trailer. Retrieved October 26, 2014, from http://intl.despicableme.com

Friedman, T. L. (2000). The Lexus and the olive tree. NY: Anchor Books.

GM Chevrolet Epica ad. (2014). Retrieved October 19, 2014, from http://epica.chevrolet.com.cn/

Hollywood Film's Chinese Elements Questioned. (May 13, 2013). International Channel Shanghai. Retrieved from http://www.icshanghai.com/information/2013-05-13/10621. html

Hollywood Films With Chinese Elements a "Reel”' Hit. (April 28, 2012). Beijing Review. Retrieved from http://www.bjreview.com.cn/movies/txt/2012-04/28/content_449680.htm

Interview. (June 1997). By one-off productions for their TV documentary McLibel: Two worlds Collide in 1997. Retrieved October 26, 2014, from http//www.mcspotlight.org/people/interviews/ritzer_george.html

Iron Man 3. (March 2014). Two minutes movie trailer. Retrieved October 28, 2014, fromhttp://v.youku.com/v_show/id_XNDY1ODE2NTI4.html

Kharas, H., \& Gertz, G. (2010). The new global Middle Class: A cross-over from West to East. Wolfensohn Center for Development at Brookings. Retrieved from http://www.brookings.edu/.../03_china_middle_class_Khras[2].pdf

Kongfu Panda 2. (Feb. 2011). Two minutes movie trailer. Retrieved October 20, 2014, from http://v.youku.com/v_show/id_XMjY4MjM0NTY4.html?from=y1.2-2.2

Laquer, W. (Sep.-Oct., 1994). Save public diplomacy: Broadcasting America’s message matters. Foreign Affair, 73(5),19-24

Leonard, M., Stead, C., \& Smewing, C. (2002). Public diplomacy. NY: Foreign Policy Center.

Little brother. (May 7, 2013). Web log comment. Retrieved from October 16, 2014,

http:// www.tudou.com/programs/viewzmoHp80u85o

Mulan. (1998). Two minutes movie trailer. Retrieved October 16, 2014, from http://movault.net/trailers/movie/Mulan_1998/520

Nye, J. Jr. (2004). Soft power. NY: Public Affairs.

Nye, J. Jr. (Mar., 2008). Public diplomacy and soft power. Annals of the American Academy of Political and Social Science, 616(96), 94-109.

Nye, J. Jr. (2012). The future of power. NY: Public Affairs.

Ritzer, G. (2008). The McDonaldization of society 5. Los Angeles: Pine Forge Press.

Shone, T. (July 25, 2014). Hollywood transformed. Financial Times. Retrieved from http://www.ft.com/cms/s/2/60338b6c-1263-11e4-93a5-00144feabdco.html

Spider Man 2 (June 2004). Two minutes movie trailer. Retrieved October 26, 2014, from http://v.youku.com/v_show/id_XMzk2MzA0Nzk2.html 
Superman: Man of Steel. (June 2013). Two minutes movie trailer. Retrieved October 28, 2014, from http://v.youku.com/v_show/id_XNDMwNjg2NTI4.html

US blockbusters perform in China, but not at home. (August 21, 2013). China Daily. Retrieved from http://www.chinadaily.com.cn/china/2013-08/21/content_16910746.htm

Wilson, E. J. (March, 2008). Hard power, soft power, smart power. Annals of the American Academy of Political and Social Science, 616, 110-124. 